\title{
KESETARAAN GENDER DAN PEMBERDAYAAN PEREMPUAN DI INDONESIA: KEINGINAN DAN KENISCAYAAN PENDEKATAN PRAGMATIS (STUDI TERHADAP UKM CIREBON HOME MADE)
}

\author{
Erna Ermawati Chotim \\ Universitas Nasional, Jakarta, Indonesia \\ Email: erna.chotim@civitas.unas.ac.id
}

\begin{abstract}
Abstrak
Mempromosikan kesetaraan gender telah menjadi kenyataan yang diakui secara global dan dapat diterima. Masalah gender juga telah diidentifikasi sebagai hal yang penting untuk pencapaian tujuan pembangunan nasional. Bahkan, pencapaian kesetaraan gender tidak hanya dilihat sebagai tujuan itu sendiri, tetapi juga sebagai katalisator, dan sine-qua-non bagi pencapaian pembangunan berkelanjutan. Penelitian ini mencoba menilai tingkat pencapaian kesetaraan gender dan pemberdayaan perempuan dengan menggunakan tiga indikator penting yaitu: partisipasi dalam pendidikan di tingkat dasar, menengah dan tinggi, pekerjaan dan pengambilan keputusan politik, memanfaatkan sumber data sekunder yang berharga. Studi ini menggunakan metode kualitatif yang dianalisis dengan pendekatan deksriptif. Narasumber adalah pemilik Cirebon Home Made. Inti masalah ketimpangan gender di Indonesia adalah dilema pemerintah Indonesia untuk mengambil keputusan untuk mengurangi masalah perluasan tingkat kapasitas yang diperlukan untuk meningkatkan kesempatan untuk mengakomodasi kebutuhan yang berbeda-beda dari keduanya. Para juga berpendapat bahwa pencapaian kesetaraan gender di Indonesia yang sudah dibatasi waktu, akan menjadi fatamorgana karena faktor penghambat multidimensi. Penelitian ini bertumpu pada aktualisasi kesetaraan gender dan pemberdayaan perempuan pada keinginan dan keniscayaan pendekatan pragmatis.
\end{abstract}

Kata Kunci: Kesetaraan Gender, Pemberdayaan Perempuan, Pendekatan Pragmatis, UKM.

\begin{abstract}
Promoting gender equality has become a globally recognized and accepted reality. Gender issues have also been identified as essential for the achievement of national development goals. In fact, the achievement of gender equality is seen not only as an end in itself, but also as a catalyst and sine qua non for the achievement of sustainable development. This study tries to assess the level of achievement of gender equality and women's empowerment using three important indicators, namely: participation in education at the primary, secondary and tertiary levels, employment and political decision-making, utilizing valuable secondary data sources. This study uses a qualitative method which is analyzed with a descriptive approach. The resource person is the owner of Cirebon Home Made. At the heart of the problem of gender inequality in Indonesia is the dilemma of the Indonesian government to take a decision to reduce the problem of expanding the level of capacity needed to increase the opportunity to accommodate the different needs of the two. Para also argues that the achievement of gender equality in Indonesia, which has been limited by time, will be a mirage due to multidimensional inhibiting factors. This research rests on the actualization of gender equality and women's empowerment on the desires and necessities of a pragmatic approach.
\end{abstract}

Keywords: Gender Equality, Women Empowerment, Pragmatic Approach, UKM. 


\section{A. PENDAHULUAN}

Secara global, semakin pentingnya kesetaraan gender telah diakui dan diterima. Kerangka normatif untuk pembangunan manusia. Hal ini tercermin dalam visi luas yang dianut dalam Tujuan Pembangunan Milenium, serangkaian tujuan yang ditargetkan dengan batas waktu yang disepakati secara internasional untuk memastikan kesetaraan gender dan memajukan peluang di berbagai sektor ekonomi global. Konvensi tentang penghapusan au bentuk diskriminasi terhadap perempuan (CEDAW) yang diadopsi pada 1979 oleh Majelis Umum PBB dan diterima oleh 180 negara menguraikan hak dan kesetaraan perempuan, kebebasan mereka dari diskriminasi, dan persamaan di bawah hokum (Hubeis, 2011).

Secara historis, perempuan secara komparatif mengalami marginalisasi, penindasan dan ketidakadilan baik dalam kehidupan publik maupun pribadi. Meskipun Deklarasi Milenium menggarisbawahi pentingnya penghapusan segala bentuk dan corak diskriminasi, eksploitasi, pelecehan social, dan bias gender serta semua situasi yang mendorong pelanggaran hak-hak perempuan melalui kebijakan dan keputusan pemerintah (Saugi, 2015). Praktik tradisional dan adat, prasangka budaya, dan ekstremisme agama, lebih banyak komitmen dan pendekatan pragmatis yang akan diterjemahkan ke dalam tindakan nyata diinginkan di seluruh dunia, khususnya di Asia \& Afrika (Marwanti, 2012). Keseimbangan antara anak laki-laki dan perempuan dalam pendaftaran sekolah dasar, misalnya, telah dicapai di sebagian besar wilayah dunia, kecuali Afrika sub-Sahara dan Asia Selatan. Kesenjangan gender dalam pendidikan tinggi juga masih berpihak pada laki-laki dan akses perempuan ke pekerjaan berbayar yang dijamin dalam hal pendapatan dan kepentingan sosial masih sangat rendah bila disandingkan dengan laki-laki di semua sektor termasuk pertanian. Namun, akses perempuan ke pengambilan keputusan politik, terutama dalam hal bagian kursi mereka di parlemen secara bertahap dan mantap meningkat secara global (Wardanty, 2020).

Pada dasarnya juga, negara-negara Asia telah menunjukkan beberapa ukuran kepedulian tentang masalah pembangunan manusia dengan memulai tujuan dan strategi pembangunan tertentu dan menerima peran penting dari kesetaraan atau paritas gender dalam proses pembangunan. Piagam Asia tentang Hak Asasi Manusia dan Rakyat (ACHPR) diadopsi pada tahun 1981; Protokol Hak Perempuan 2003; Protokol ECOWAS tentang Demokrasi dan Pemerintahan yang Baik dan Kemitraan Baru untuk Pembangunan Asia (NEPAD) yang diadopsi pada tahun 2001 adalah beberapa inisiatif yang terkait dengan Tujuan Pembangunan Milenium dan pada saat yang sama, sebuah kesaksian atas tanggapan yang terpuji di benua Asia (Mulyana, 2017).

Aktualisasi tujuan kesetaraan gender dan pemberdayaan perempuan di Indonesia adalah tugas yang sangat berat (Faqih, 2020). Aktualisasinya bagaimanapun bergantung atau didasarkan pada sejumlah kondisi, yang tidak dapat dihindari. Kebenaran dari pernyataan di atas juga terbukti dalam kenyataan bahwa kondisi tidak hanya preseden untuk pencapaian tujuan Pembangunan Milenium yang telah disebutkan sebelumnya tetapi pendekatan pragmatis pada dasarnya adalah desideratum. Saat ini, penting untuk dicatat bahwa karena realisasi kesenjangan yang diciptakan oleh marjinalisasi dan ketidakadilan sosial terhadap perempuan dan hilangnya mata rantai dalam agenda pembangunan oleh terbatasnya akses ke peluang yang ada di hampir semua sektor sosial-politik dan ekonomi. Pengaturan, wanita secara bertahap datang ke depan publik. Penjelasan yang masuk akal untuk tren dan perkembangan ini adalah pemikiran bahwa salah satu indikator kemajuan dan perkembangan 
suatu bangsa adalah posisi perempuan dalam masyarakat itu (Butarbutar, 2020). Oleh karena itu, perempuan dipandang sebagai alat untuk perubahan positif, tujuan yang bergantung pada tingkat akses ke peluang untuk mengaktualisasikan potensi dan bakat mereka.

Selain itu, mempromosikan kesetaraan gender untuk aktualisasi perlindungan hak asasi manusia sangat penting bagi seluruh kepedulian terhadap pembangunan manusia yang berpusat pada memungkinkan orang untuk menjalani kehidupan yang mereka hargai dan memungkinkan mereka untuk mewujudkannya (Sugiarti, 2020). Potensi sebagai manusia. Menyadari meningkatnya kebutuhan akan kesetaraan gender juga terkait dengan kelangsungan hidup dan perkembangan anak-anak dan pembangunan komunitas, masyarakat dan bangsa yang sehat. Kesenjangan antara Tujuan Pembangunan Milenium untuk mempromosikan kesetaraan Gender dan aktualisasinya di Indonesia (Widiastuti, 2017). Bagaimanapun, adalah dilema tindakan oleh pemerintah Indonesia yang dicirikan oleh salah pemerintahan, kurangnya kemauan politik, budaya patriarki yang berlaku, investasi publik yang salah dan ketiadaan kapasitas produktif yang memadai akan menciptakan peluang bagi pemberdayaan dan pembangunan perempuan (Ganiem, 2017). Masalah ini menjelaskan keniscayaan dan keharusan dari pendekatan pragmatis berbasis tindakan yang akan menerjemahkan program kesetaraan gender menjadi kenyataan konkret. Hal ini terutama karena tugas pencapaian target kesetaraan gender di Indonesia pada tahun 2019 tidak hanya memerlukan kebijakan pasif yang terpisah dan berbeda dari pelaksanaan, tetapi proses aktif yang mencakup analisis yang tepat, definisi tujuan, program tindakan, dan hasil pemantauan.

\section{B. METODE}

Tahap pertama dalam penelitian ini adalah mencari data dasar teori dari faktor-faktor yang menjadi fondasi UKM industri kreatif yang dapat meningkatkan pemberdayaan perempuan di Indonesia. Untuk melakukan tinjauan pustaka diidentifikasi beberapa kata kunci yang terdiri dari pemberdayaan perempuan, faktor bisnis, indikator usaha, pemberdayaan perempuan di negara berkembang

Tahap selanjutnya adalah melakukan survey lapangan pada salah satu kawasan industri kreatif UKM yaitu Cirebon Home Made yang berlokasi di Jalan Cipto Mangunkusumo Kota Cirebon Jawa Barat sebagai objek penelitian. Lihat cara kerja sistem dari awal proses hingga akhir proses. Artinya sampai produk terjual ke pelanggan. Tidak hanya proses bisnis tetapi juga manajemen bisnis. Selain itu penelitian ini juga bertujuan untuk mencari informasi data kualitas, rencana tata letak, pencatatan kepegawaian dan berbagai laporan lainnya yang diperiksa.

Tahapan terakhir adalah pendalaman eksplorasi untuk dijadikan perbandingan dengan faktor-faktor yang telah dikemukakan adalah melakukan wawancara langsung pada pemilik Cirebon Home Made. Selain pemilik bisnis, wawancara juga dilakukan terhadap karyawan. Kekurangan dari wawancara tersebut yang dilakukan oleh kurangnya pendidikan karyawan UKM menyebabkan kurang tersampaikannya maksud dan tujuan, sehingga sebagian jawaban dari pertanyaan wawancara dianggap kurang memuaskan. Namun hasil yang diperoleh cukup mewakili tujuan penelitian ini yang diharapkan dapat menjadi acuan bagi perempuan pengusaha lainnya untuk dapat melaksanakan atau mengembangkan usahanya. 


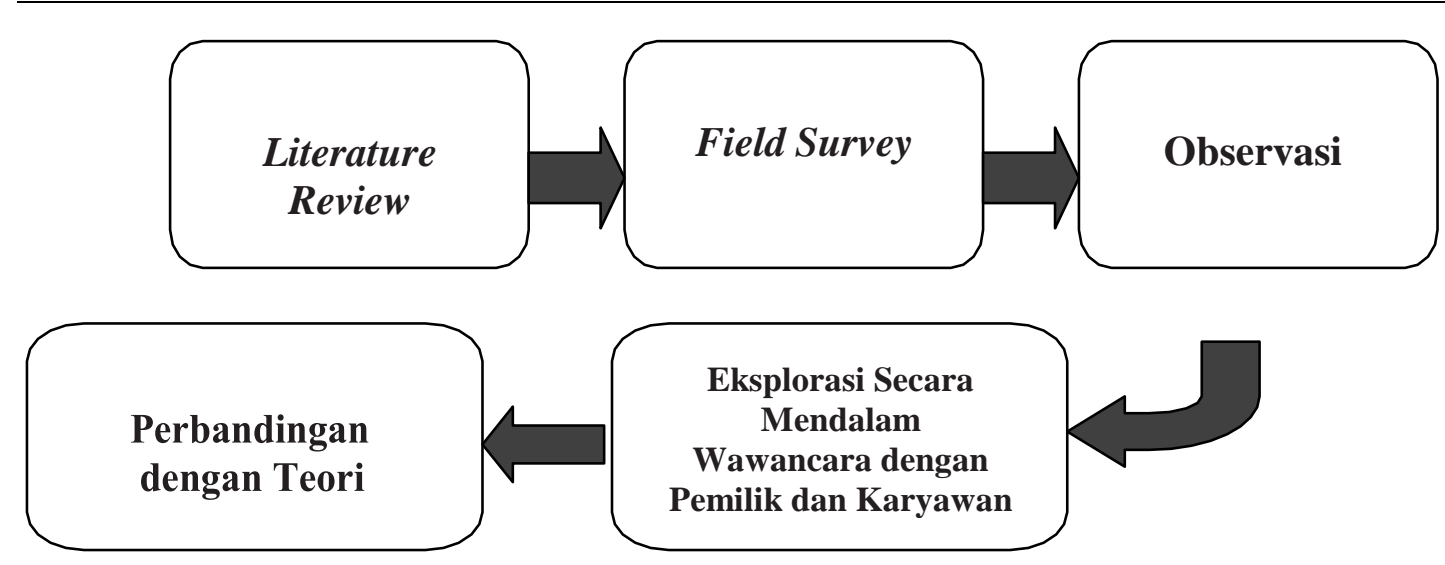

Gambar 1 Alur Metodologi Penelitian

\section{HASIL DAN PEMBAHASAN}

\section{Tinjauan Umum Cirebon Home Made}

Cirebon Home Made merupakan salah satu UKM di Kota Cirebon yang berlokasi di Jalan Mangunkusumo. Pemilik usaha ini adalah keluarga Bapak Didi dan Ibu Farida Prayudi yang mempunyai bakat seni sulam pita. Sejarah terbentuknya usaha ini tepatnya pada tahun 1997, seorang teman dari pasangan yang meminta bantuannya membuat silabus untuk mengajarkan keterampilan membordir pita untuk diajarkan kepada ibu-ibu rumah tangga di Provinsi Riau. Pemicuan silabus yang diajarkan kepada mereka tentang kerajinan sulam pita di daerah Cirebon bagi ibu rumah tangga yang ingin belajar tentang kerajinan tangan dan akhirnya menjadi guru di sebuah perusahaan kerajinan tangan. Pada tahun 2004, Cirebon Home Made fokus memproduksi barang jadi dari kerajinan sulam pita, dan memiliki showroom untuk memajang barangnya ke pasaran.

Cirebon Home Made fokus pada pekerjaannya, diajarkan bukan lagi hal utama dalam mengembangkan usahanya, mereka melakukan produksi besar-besaran untuk mengembangkan usaha. Salah satu pemilik Cirebon Home Made telah meninggal dunia dan kini hanya dipimpin oleh Ibu Farida Prayudi. Pada awalnya karyawan Cirebon Home Made berjumlah 30-40 orang, namun saat ini hanya memiliki karyawan setia secara keseluruhan sebanyak 10 orang yang berasal dari kalangan ibu rumah tangga yang tidak mempunyai pekerjaan lain dan menjadikan pekerjaan ini sebagai pekerjaan utama mereka.

Pendapatan produk yang ditawarkan adalah produk tas koleksi sulam pita, cover kotak, dan pelindung kap lampu atau vas bunga. Sistem kerja dalam usaha ini adalah mengajarkan dasar-dasar pembuatan sulaman pita pada karyawan terlebih dahulu kemudian pemilik membuat beberapa pola pada kain atau kotak tersebut. Pola tersebut kemudian dibagikan pada karyawan untuk dijadikan barang jadi di rumah sendiri milik karyawan dengan batas waktu yang ditentukan sesuai tingkat kesulitan polanya. Sebagai satu-satunya pengurus dalam bisnis, Ibu Farida Prayudi menjadi orang yang membuat sistem pembayaran untuk mengelola karyawannya dan juga sistem pelatihannya, namun tidak secara terbuka merekrut untuk menjadi. Ibu Farida akan mengajarkan sulaman pita rajut dasar yang sesuai dengan kemampuan untuk menyamai., namun tetap mempertahankan orisinalitas karyanya dengan membuat pola yang berbeda setiap kali produk baru yang muncul itu berasal dari 
idenya sendiri. Dia juga tidak khawatir dengan karyawannya yang berhenti dan mendirikan bisnis serupa dengannya.

Sedangkan sistem penggajian karyawan dihitung berdasarkan jumlah produk yang dihasilkan dari masing-masing karyawan, dilihat juga dari tingkat kesulitan produk yang mereka buat. Setiap produk harus dibuat oleh karyawan dan kemudian 5\% dari penjualan menjadi upah karyawan. Sedangkan sisanya menjadi pendapatan Cirebon Home Made, sebagian besar untuk biaya bahan baku produk. Pemasaran produk Cirebon Home Made pernah mencapai Amerika Serikat pada tahun 2010 silam, namun adanya permasalahan dalam bisnis ini yaitu para karyawan menduplikasi karya yang dijual ke luar negeri. Selama ini Cirebon Home Made melakukan pemasaran di Indonesia hanya menggunakan pemasaran dari mulut ke mulut, sesekali karya seni hasil produksi Cirebon Home Made juga mengikuti bazar yang diselenggarakan oleh INACRAFT (salah satu komunitas pengrajin). Produk yang dijual sampai saat ini hanyalah produk yang sesuai dengan pesanan saja.

Setelah dilakukan kajian pustaka, ditemukan teori-teori yang dapat menunjukkan faktor-faktor yang mempengaruhi pemberdayaan perempuan. Setelah survei lapangan, observasi dan eksplorasi mendalam Cirebon Home Made, peneliti mendapat gambaran tentang implementasi pemberdayaan perempuan di daerah tersebut. Tinjauan ini kemudian dibandingkan dengan studi teoritis yang diperoleh dari tinjauan pustaka. Ada beberapa faktor yang akan dibahas yaitu gaya kepemimpinan, pelatihan dan pembelajaran, latar belakang pendidikan, sumber daya, prestasi, pengalaman, kebutuhan otonomi, panutan dan komitmen manajemen.

Berdasarkan penjelasan kriteria-kriteria yang terdapat pada factor gaya kepemimpinan, Cirebon Home Made memiliki implementasi yang sangat tinggi dengan memperhatikan beberapa kriteria, yaitu berbagi kekuasaan dan informasi, memotivasi orang lain, mendorong minat pada tujuan kelompok, dan partisipatif (Ganiem, 2017). Berbagi kekuatan dan informasi dijadikan nilai dari pemimpin dalam bisnis tersebut karena bisnis lebih ditekankan untuk menyebarkan ilmu agar lebih banyak wanita yang bisa berkarya di Indonesia untuk seni sulam pita. Ibu Farida adalah orang yang paling berjasa dalam memotivasi para pekerjanya agar lebih baik dalam menghasilkan karya, dan juga melakukan dorongan minat dari kelompok pengusaha wanita yang memiliki tujuan awal ingin berjualan di kota Cirebon dengan permintaan yang tinggi untuk mencoba merambah dunia internasional yang bisa berjualan ke Amerika Serikat. Melakukan berbagai partisipasi dalam pameran-pameran nasional dan internasional untuk mengembangkan bisnis. Pada kepemimpinannya, dirasakan kurangnya kerjasama yang dilakukan pihak lain di luar perusahaan pemasok bahan baku kerajinan. Selain itu juga memiliki kecepatan belajar yang lamban tentang masalah organisasi sehingga perkembangan bisnis menjadi sangat lambat. Berdasarkan faktor lainnya, gaya kepemimpinan merupakan faktor yang mempengaruhi jalannya usaha ini.

Pembelajaran dan pelatihan berkelanjutan adalah poin sentral untuk pemberdayaan. Cirebon Home Made melaksanakan pelatihan berkelanjutan dalam melakukan produksi sulam pita secara terus menerus dengan pola yang semakin kompleks. Dalam hal ini, para pekerja terus mengasah kemampuannya untuk menghasilkan produk tersebut dengan kualitas yang baik dan waktu pengerjaan yang lebih cepat. Sehingga semakin lama kemampuan karyawan meningkat. Sedangkan pembelajaran yang dilakukan oleh Ibu Farida banyak sekali 
cara untuk menyebarkan ilmunya kepada komunitas wanita lain di kota Cirebon. Dikerjakan tanpa upah yang begitu tinggi, namun member memberikan kesempatan kepada mahasiswa untuk dapat bekerja di perusahaannya. Faktor ini juga menjadi faktor yang sangat berpengaruh dalam perkembangan bisnis Cirebon Home Made selain dari faktor gaya kepemimpinan.

Pendidikan merupakan aspek kunci dalam pengentasan kemiskinan. Dilihat dari penyelenggaraan Cirebon Home Made, pemilik usaha ini yaitu Ibu Farida memiliki jenjang pendidikan yang lebih tinggi sampai dengan jenjang S1. Dengan hal ini kemampuan menata dan berfikir untuk manajemen bisnis dapat terlaksana dengan baik. Berbeda sekali dengan karyawan bisnis Cirebon Home Made yang umumnya tidak berpendidikan tinggi, rata-rata tamat SMP atau SMA. Kemiskinan memang menjadi masalah utama dalam hidup mereka, namun dengan mempelajari kerajinan yang dibuat setidaknya mereka memiliki bekal untuk mengembangkan keterampilannya untuk dapat menambah income.

Untuk usaha kecil menengah seperti Cirebon Home Made, 10 orang karyawan dirasa kurang sesuai dengan kapasitas pekerjaan yang ada di bisnis ini. Ada saat dimana bisnis ini memiliki permintaan yang tinggi dari pelanggan sehingga mereka membutuhkan lebih banyak karyawan untuk menyelesaikan semua pesanan. Sedangkan pada saat permintaan rendah, terjadi kesulitan pembiayaan pembelian bahan baku karena minimnya pendapatan. Eksekusi produk terus dilakukan tanpa henti meski permintaan produk dari pelanggan kecil. Teknik alokasi pekerjaan telah diterapkan pada bisnis manajemen kinerja. Bagi pekerja yang baru dan kurang ahli, akan diberikan sulaman pita dengan pola yang mudah dibuat, sedangkan jika karyawan memiliki skill tinggi dan kecepatan pengerjaan produk yang tinggi maka akan diberikan tugas yang lebih dari pada karyawan lainnya.

Cirebon Home Made telah meraih prestasi terbaiknya yaitu mampu memperluas pasar dan produknya hingga ke tingkat Internasional yaitu negara bagian Amerika Serikat. Pencapaian tersebut dapat meningkatkan nama bisnis dan banyaknya permintaan dari pelanggan yang nantinya dapat mengembangkan skala bisnis. Dengan pencapaian tersebut maka akan meningkatkan kinerja karyawannya menjadi lebih ketat dari segi kuantitas, waktu, dan kualitas produk. Untuk mencapai pencapaian yang diinginkan, faktor-faktor lain yang memiliki pengaruh besar terhadap pencapaiannya. Sehingga perlu adanya peningkatan kualitas dari berbagai faktor untuk mendukung pencapaian yang dilakukan. Atas prestasi Cirebon Home Made yang mereka peroleh beberapa tahun kemudian justru membawa hal buruk bagi mereka, akibat pencurian karya yang dipasarkan di luar negeri oleh karyawan, proyek tersebut dihentikan. Dari hal ini dapat disimpulkan bahwa kemauan maksimal yang ingin dicapai oleh perempuan pengusaha jika tidak didukung oleh lingkungan belum tentu berhasil.

Jika pengalaman merupakan faktor penting lain dalam mengembangkan bisnis, bisnis sulam pita Cirebon Home Made diikuti oleh istri dari pemilik asli usaha ini yang sebenarnya dia yang memiliki pengalaman dalam kerajinan sulam pita. Istrinya Ibu Farida tidak memiliki pengalaman sama sekali dalam membuat produk, mendesain pola sulam pita dan menjalankan usaha. Dia belajar sejak suaminya meninggal. Dengan niat yang sangat kuat untuk membiayai keluarga, Ibu Farida mulai percaya diri dalam menjalankan bisnisnya. Dia belajar mengelola karyawan, mencari bahan mentah, menemukan pasar dari pengalaman nol. Namun, hingga saat ini usahanya berjalan cukup lancar dan ia sudah berani mendidik 
anaknya dalam menjalankan usahanya tersebut.

Otonomi merupakan salah satu faktor UKM yang dipimpin oleh perempuan. Otonomi diberikan oleh pimpinan bisnis kepada karyawan di bidang pembuatan sulam pita. Tidak ada otonomi yang diberikan oleh Ibu Farida untuk pola yang akan dibentuk dan juga batas waktu penyelesaian produk, sedangkan tempat kerja dan sistem kerja juga diserahkan sepenuhnya kepada pekerja. Mereka mudah untuk memimpin diri sendiri, tidak memandang kinerja karyawan lain dan peraturan serta kebebasan yang mereka peroleh untuk mengambil keputusan untuk pekerjaannya masing-masing. Dari segi manajemen, Ibu Farida memberikan otonomi pada kinerjanya dengan tidak melihat trend yang ada di masyarakat. Dia melakukan otonomi untuk merancang pembuatan pola sendiri dan kebebasan untuk memproduksi barang baru tanpa permintaan pelanggannya. Pelanggan memiliki sedikit otoritas dalam menentukan jenis produk yang ingin mereka pesan. Dari uraian tersebut dapat disimpulkan bahwa setiap pegawai pada usaha ini memiliki kemandirian masing-masing.

Role Model sangat diperlukan dalam meningkatkan motivasi wirausaha. Faktor ini Memicu semangat karyawan untuk terus berkarya menjalankan bisnis. Ibu Farida selaku pemilik Cirebon Home Made mendapatkan motivasi yang besar dari panutannya yaitu suaminya sendiri Pak Didi. Dia memberikan kepadanya motivasi terbaik untuk bekerja dan terus menjalankan bisnis keluarga untuk kehidupan finansial keluarga mereka. Sejak suaminya meninggal, Ibu Farida semakin terpacu mengembangkan usahanya pasca suaminya meninggal. Kini, Ibu Farida menjadi role model bagi para pekerja wanita di bidang kerajinan sulam pita. Dia mendorong para wanita untuk tetap semangat, dia menjadi guru bagi para pekerja dan mempengaruhi mereka untuk membuat perbedaan dan menjadi sosok yang menginspirasi bagi para pekerja.

Komitmen dijaga dengan baik dalam bisnis ini sementara pemimpinnya selalu menjaga nilai dari bisnis ini, yaitu pemberdayaan perempuan perempuan di sekitar daerah agar mampu dan memiliki keahlian membuat kerajinan sulam pita. Sifat saling percaya antar karyawan terjaga dengan baik dan setiap karyawan memegang teguh tanggung jawab atas pekerjaannya masing-masing. Dari penjelasan tersebut, sikap telah menyebabkan jalannya suatu bisnis dapat bertahan dan berkembang hingga saat ini.

\section{Kesetaraan Gender dan Pemberdayaan Perempuan di Indonesia}

Kesetaraan gender dan pemberdayaan perempuan telah menjadi salah satu tema sentral dalam perjanjian, kovenan dan deklarasi global terutama karena pemahaman bahwa ini adalah katalisator untuk strategi pembangunan yang jelas yang ditargetkan pada pengurangan kemiskinan, peningkatan standar hidup, tata kelola yang baik dan investasi produktif yang menguntungkan yang sangat penting untuk penciptaan kapasitas yang lebih besar yang memberikan kesempatan yang sama bagi laki-laki dan perempuan dan akses tak terbatas ke lembaga dan proses pengambilan keputusan dan implementasi kebijakan (Tjiptaningsih, 2018).

Di Indonesia, beberapa upaya terpuji telah dilakukan untuk menerapkan mekanisme yang diperlukan untuk penghapusan diskriminasi gender untuk memastikan kesetaraan gender dan martabat manusia. Kebijakan Gender Nasional, yang menggantikan dan memperkuat Kebijakan Nasional Perempuan sebelumnya, secara khusus ditujukan pada masalah ketidaksetaraan gender di Indonesia. Menghadapi hal-hal di atas, sejarah kebijakan 
pembangunan di Indonesia agaknya adalah sikap lesu terhadap variabel gender (Tini, 2019). Dua dekade pertama perencanaan pembangunan di Indonesia dari tahun 1963 ketika menjadi Republik, misalnya, sebagian besar dicirikan oleh kebijakan pembangunan yang buta gender dan tidak sensitif gender. Dalam nada yang sama, Indonesia, terutama sejak kebangkitan tahun 1980-an, menganut kebijakan ekonomi bias gender di mana kepentingan perempuan dimasukkan dalam kepentingan nasional dan sensitivitas gender hampir tidak penting, sangat kecil dan tidak menjadi masalah (Imaniar, 2017).

Dengan diadopsinya Tujuan Pembangunan Milenium oleh Perserikatan BangsaBangsa pada bulan September 2000, lebih banyak minat telah dihasilkan dan perhatian yang lebih baik diberikan pada pengejaran kebijakan sensitif gender di tingkat global dan nasional. Secara khusus, tujuan ketiga, yang ditujukan untuk mencapai kesetaraan gender dan pemberdayaan perempuan, keduanya memiliki nilai intrinsik dan sekaligus inti dari pencapaian semua tujuan lainnya (Syarif, 2018). Ini pada dasarnya karena Deklarasi Milenium Perserikatan Bangsa-Bangsa menyatakan bahwa jika wanita diberikan kebanggaan atas tempat mereka dalam sejarah, gerakan dan perkembangan membantu proses secara efektif memerangi kemiskinan, kelaparan, penyakit dan merangsang pembangunan berkelanjutan. Setidaknya, sampai jumlah anak perempuan dan laki-laki yang sama bersekolah di semua tingkat pendidikan, tidak mungkin membangun pengetahuan yang diperlukan untuk memberantas kemiskinan dan kelaparan, memerangi penyakit, dan memastikan kelestarian lingkungan. Tolok ukur untuk menilai tingkat pencapaian kesetaraan gender dan pemberdayaan perempuan mencakup partisipasi dalam pendidikan di tingkat dasar, menengah dan tinggi, pekerjaan serta pengambilan keputusan politik.

Indikator kedua untuk menentukan pencapaian Tujuan Pembangunan Milenium dalam hal kesetaraan gender dan pemberdayaan perempuan adalah lapangan kerja. Data yang ada menunjukkan bahwa terdapat kesenjangan yang lebar antara penghasilan dan kesempatan kerja perempuan dan laki-laki di hampir semua sektor masyarakat Indonesia (Bakar, 2017). Keterlibatan perempuan di sektor industri diperkirakan 11\% dibandingkan dengan $30 \%$ untuk laki-laki, sementara partisipasi perempuan dalam kegiatan yang menghasilkan pendapatan yang sebagian besar ditandai dengan kerja manual yang intens seperti pertambangan dan penggalian hampir tidak ada terutama karena jenis kelamin. Persepsi terkait tentang konstruksi sosial tenaga kerja dan kegiatan yang berhubungan dengan produksi. Sebanyak $76 \%$ pegawai negeri adalah laki-laki dan $24 \%$ adalah perempuan. Sedangkan perempuan menempati posisi kurang dari $14 \%$ dari total jabatan tingkat manajemen, sedangkan $17,5 \%$ yang bergerak di bidang kesehatan adalah perempuan dibandingkan dengan 82,5\% laki-laki (Tamba, 2020).

Selain itu, indikasi lain dari disparitas gender menunjukkan bahwa laki-laki yang terlibat di sektor formal adalah sekitar $87 \%$ dibandingkan dengan $11 \%$ perempuan, sementara industri ekstraktif dengan volume bisnis tahunan lebih dari US \$ 42 juta hampir tidak memiliki tingkat keterlibatan perempuan (Sugiarti, 2020). Norma dan nilai yang diinduksi oleh gender sama-sama menugaskan perempuan untuk tugas rumah atau manajemen rumah tangga dan ini berpotensi menghalangi perempuan untuk mengejar karir mereka ke posisi manajemen puncak dan kader pengambilan keputusan pada tingkat, frekuensi, dan gaya yang sama seperti rekan laki-laki mereka pada dasarnya di semua sektor masyarakat Indonesia (Widianto, 2018). Tidak heran, di antara $70 \%$ populasi yang diperkirakan hidup di bawah 
garis kemiskinan di Indonesia, lebih dari 65\% diperkirakan adalah wanita, terutama karena pendapatan dan daya beli wanita diperkirakan sebesar US \$ 1.495 dibandingkan dengan US \$ 614.

Untuk laki-laki yang juga memiliki akses ke pekerjaan bergaji tinggi, aman dan stabil. Faktanya, meskipun perempuan telah diangkat menjadi kader sekretaris tetap mulai tahun 2017 seiring dengan inisiatif aksi afirmatif, tingkat disparitas antara laki-laki dan perempuan dalam hal pekerjaan di Indonesia berdampak signifikan pada kapasitas perempuan untuk bekerja. Berkontribusi pada pertumbuhan dan pembangunan ekonomi. Ada beberapa faktor yang berpotensi menghambat efektivitas kebijakan dan program kesetaraan gender dan sensitif gender, dan sebagai konsekuensinya adalah aktualisasi Kesetaraan Gender dan Pemberdayaan Perempuan di Indonesia. Faktor-faktor tersebut meliputi:

a. Budaya Patriarkal

Budaya sentral yang meresap ke dalam masyarakat Indonesia bersifat patriarkal. Budaya yang didominasi laki-laki ini menempatkan perempuan pada posisi inferior dan sekunder dalam masyarakat. Budaya patriarki dari supremasi laki-laki masih tetap tertanam, dikaburkan, dan dilindungi dalam institusi dan struktur tradisional yang dijaga ketat dan relatif paling sakral. Tantangan utama untuk tugas melaksanakan kebijakan sensitif gender dan paritas gender di Indonesia, oleh karena itu, adalah norma, sikap, dan praktik budaya patriarki, yang telah diterima sebagai tatanan alam. Budaya ini masih melekat pada laki-laki dan itu ditunjukkan baik secara sadar maupun tidak sadar, terlepas dari dorongan umum untuk perubahan yang berarti dalam hubungan gender melalui inisiatif dan tindakan kebijakan serta berbagai konvensi dan kesepakatan internasional yang ditandatangani Indonesia (Kurniawanto, 2019).

b. Kapasitas Tidak Memadai

Pengembangan kapasitas dan pemanfaatan telah dengan tegas diperdebatkan sebagai mata rantai yang hilang dalam pembangunan Indonesia. Tingkat pembangunan kapasitas dalam masyarakat mana pun dapat diukur atau dinilai menggunakan kriteria atau indikator keuangan, manusia, kelembagaan dan infrastruktur (Haramain, 2019). Terlepas dari sumber daya keuangan yang besar di Indonesia, kualitas sumber daya manusia, kelembagaan dan infrastruktur dinilai sangat tidak memadai. Kapasitas yang tidak memadai telah sangat mempengaruhi sumber daya publik; program, proyek dan kegiatan dikelola dan dikoordinasikan di Indonesia. Akibatnya kemampuan merumuskan, menganalisis dan melaksanakan kebijakan dan program untuk pencapaian tujuan dan aspirasi pembangunan nasional sangat terkendala. Oleh karena itu, kapasitas yang buruk untuk menangani program-program sosio-ekonomi di Indonesia disebabkan oleh investasi publik yang salah dalam lembaga dan proses untuk pembangunan kapasitas dan pembongkaran lingkungan pendukung secara bertahap untuk memelihara dan meningkatkan kapasitas yang ada. Inti dari masalah pencapaian Tujuan Pembangunan Milenium tentang kesetaraan gender dan pemberdayaan perempuan di Indonesia bisa dibilang adalah kapasitas yang tidak memadai (Fakih, 2020).

c. Keinginan Politik dan Komitmen

Menciptakan masyarakat yang ramah gender, responsif, adil, dan egaliter menuntut 
dukungan penuh dari semua tingkatan atau tingkatan pemerintahan, terutama Pemerintah Federal yang merumuskan kebijakan umum atau makro yang diharapkan dapat memberikan arahan bagi kebijakan dan kegiatan mikro di tingkat pemerintahan yang lebih rendah (Indriani, 2019). Untuk tujuan ini, eksekutif, legislative, dan Yudikatif harus menerima, merangkul dan menunjukkan komitmen melalui prinsip dan praktik paritas gender yang jelas. Komitmen tersebut tercermin pada tingkat partisipasi, iklim yang mendukung dan investasi produktif dalam hal sumber daya keuangan dan waktu. Setelah semua hal di atas ada, komitmen tidak hanya dilihat oleh pemangku kepentingan lain seperti organisasi swasta dan masyarakat sipil dan individu, tetapi juga memberikan dukungan dan kerja sama yang erat untuk mewujudkan tujuan kesetaraan gender dan pemberdayaan perempuan di Indonesia (Diwanti, 2019). Untuk tujuan ini, kebijakan, kemitraan, dan reformasi program melalui komitmen terhadap kepedulian gender di semua tingkatan merupakan suatu desideratum. Meskipun pemerintah Indonesia telah banyak menyatakan komitmennya terhadap kesetaraan gender dan pemberdayaan perempuan, lingkungan kebijakan yang ada lintas sektor, kerjasama antar sektor, dan prioritas program mempercayai komitmen ini yang lebih teoretis daripada pragmatis (Ibrahim, 2019). Pada kenyataannya, lingkungan kebijakan yang relatif toleran saat ini didahului oleh rezim perlawanan terhadap kesetaraan gender. Penjelasan yang mungkin untuk suasana sikap lesu sebelumnya terhadap kesetaraan gender di Indonesia adalah konsepsi lemah paten tentang implikasi penyeimbangan gender untuk pembangunan nasional yang berkelanjutan. Hal yang benar dari penalaran di atas terbukti dalam kenyataan bahwa dalam dua puluh sembilan tahun terakhir, telah terjadi pergeseran dari melihat ketidaksetaraan gender sebagai sebuah isu yang hanya mempengaruhi perempuan (Indrawati, 2017).

\section{Partisipasi dan Kemitraan oleh Pemerintah dan Pemangku Kepentingan Non- Pemerintah}

Mencapai kesetaraan gender dan pemberdayaan perempuan di Indonesia menuntut partisipasi dan kemitraan oleh pemerintah Indonesia di semua tingkatan dan organisasi nonpemerintah serta kelompok masyarakat sipil (Sujarwo, 2017). Meskipun mitra pemerintah terutama bertanggung jawab, terutama karena mereka diharapkan menyediakan lingkungan kebijakan serta tindakan yang diperlukan untuk mendorong dan mengoordinasikan upaya berbagai pemangku kepentingan, semua mitra harus memainkan peran penting mereka dalam aktualisasi kemitraan yang terdefinisi dengan baik.

Pengaturan, program dan mekanisme penyampaian layanan. Pemerintah juga harus memenuhi tantangan dalam mendefinisikan kebijakan gender yang sejalan dan berdampak positif pada tujuan pembangunan secara keseluruhan. Hal ini akan melampaui konseptualisasi hukum tentang kesetaraan gender ke dalam konteks pembangunan yang lebih luas yang akan membutuhkan peralatan ulang kerangka kerja pembangunan yang akan disesuaikan dengan kesetaraan gender dan penggabungan perspektif gender ke dalam semua aspek perumusan kebijakan, arahan dan aktualisasi. Selain itu, kegiatan berbagai kementerian, lembaga, dan lembaga non-pemerintah harus diperkuat, disintesis, terintegrasi, dan terfokus dengan baik sehingga dapat memfasilitasi proses partisipasi dan kemitraan semua pemangku kepentingan 
(Rachmawati, 2018).

Efek yang menyertainya adalah terpeliharanya masalah gender di seluruh sektor dan di semua tingkatan. Singkatnya, kebutuhan untuk membangun kemitraan yang efektif antara sektor pemerintah dan non-pemerintah dan kelompok masyarakat sipil untuk tujuan mempromosikan prinsip dan praktik kesetaraan gender untuk pencapaian tujuan tidak dapat terlalu ditekankan.

Tren sosio-budaya yang mendukung dan mendorong ketidaksetaraan atau disparitas gender di Indonesia telah menciptakan iklim konservatisme dan perlawanan terhadap sentralitas peran kesetaraan gender dalam mencapai pembangunan nasional secara berkelanjutan. Oleh karena itu, diperlukan re-orientasi oleh individu, kelompok, lembaga dan lembaga (baik pemerintah maupun non-pemerintah) pada isu-isu kesetaraan gender yang diterjemahkan ke dalam perubahan sikap dan respon, yang erat untuk kemanjuran kesetaraan gender dan perempuan. Pemberdayaan di Indonesia. Oleh karena itu, budaya penghormatan terhadap hak asasi manusia dan gender di Indonesia perlu dilembagakan.

Untuk mencapai tujuan Deklarasi Milenium tentang kesetaraan gender membutuhkan penciptaan, peningkatan dan penguatan kapasitas manusia, kelembagaan dan infrastruktur yang berkelanjutan (Supriyanti, 2017). Kapasitas yang memadai seperti itu perlu melibatkan pembangunan struktur dan penyediaan keterampilan teknis, lembaga, dan proses yang diperlukan untuk memfasilitasi dan mengoordinasikan rencana dan tindakan strategis untuk melahirkan dan mempertahankan perubahan yang diinginkan yang merupakan inti dari penghapusan disparitas dan ketidaksetaraan gender di Indonesia. Setidaknya, keharusan untuk menutup kesenjangan gender dan meningkatkan keadilan sosial, khususnya di tingkat kebijakan di Indonesia tidak lagi menjadi kontroversi. Namun sayangnya, keahlian teknis gender yang tidak memadai, kapasitas manusia dan kelembagaan telah sangat mengganggu dan menghambat aktualisasi tujuan gender multi-sektoral dengan implikasi negatif bagi pembangunan nasional secara keseluruhan di Indonesia.

\section{KESIMPULAN}

Cirebon Home Made telah memberikan contoh pembangunan atmosfer ramah Gender karena perusahaan telah sukses dan dipimpin oleh seorang wanita. Namun budaya ini belum didukung oleh pemerintah dengan menjalin kemitraan serta pengembangan pada level UKM, karena masih banyaknya faktor yang menghambat aktualisasi kesetaraan Gender dan pemberdayaan perempuan di Indonesia. Membangun masyarakat yang ramah gender yang bebas dari semua sisa diskriminasi dan ketidaksetaraan sehingga dapat memanfaatkan potensi penuh dari semua kelompok sosial dan mempromosikan prinsip-prinsip hak asasi manusia yang fundamental adalah tujuan dari Tujuan Pembangunan Milenium tentang Kesetaraan Gender dan Pemberdayaan Perempuan.

Mencapai tujuan di atas tidak hanya diperlukan untuk upaya pembangunan berkelanjutan di Indonesia; hal ini juga menuntut pendekatan pragmatis untuk perumusan kebijakan yang tepat, desain program, implementasi yang terfokus dan pemantauan dan evaluasi yang efektif dalam iklim kemauan politik yang ramah, komitmen yang tulus dan pemulihan nasional orientasi. Namun pada kenyataannya, meskipun terdapat tantangan statistik yang akurat, andal dan kredibel tentang kemajuan yang dicapai dalam tujuan kesetaraan gender dan pemberdayaan perempuan, statistik dan bukti yang tersedia 
menunjukkan bahwa target tahun 2020 sudah sangat buruk. Namun demikian, pemerintah di semua tingkatan dalam kemitraan kerja sama dengan pemangku kepentingan lainnya di Indonesia harus meningkatkan upaya agar kemajuan yang berarti dapat dicapai dengan cara yang berkembang. Dalam arah ini, berbagai organ, lembaga, dan lembaga pemerintah harus diperkuat untuk efisiensi kebijakan dan kinerja sektoral yang dipercepat.

\section{DAFTAR PUSTAKA}

Bakar, H. A. (2017). Pemetaan Pusat Pelayanan Terpadu Pemberdayaan Perempuan dan Anak (P2TP2A) Provinsi Sumatera Barat. Kafaah: Journal of Gender Studies, 7(1), 107-122.

Butarbutar, D. N., Sintani, L., \& Harinie, L. T. (2020). Peningkatan Kesejahteraan Ekonomi Masyarakat Pesisir Melalui Pemberdayaan Perempuan. Journal of Environment and Management, 1(1), 31-39.

Diwanti, D. P., Andriyani, E., \& Herawati, R. S. (2019). Pemberdayaan Perempuan Melalui Bina Usaha Ekonomi Keluarga 'Aisyiyah (BUEKA). NUSANTARA: Jurnal Ilmu Pengetahuan Sosial, 6(2), 194-207.

Faqih, A. (2020). Pemberdayaan Perempuan Melalui Pemanfaatan Dan Penataan Pekarangan. Abdimas Galuh, 2(1), 1-11.

Faqih, A. (2020). Pemberdayaan Perempuan Melalui Pemanfaatan Dan Penataan Pekarangan. Abdimas Galuh, 2(1), 1-11.

Ganiem, L. M. (2017). Pemberdayaan Perempuan Miskin Kota Melalui Pendidikan. Jurnal Aspikom, 3(2), 239-255.

Haramain, M. (2019). Dakwah Pemberdayaan Perempuan: Telaah Pemikiran Qasim Amin Tentang Kesetaraan Gender. Zawiyah: Jurnal Pemikiran Islam, 5(2), 218-235.

Hubeis, A. V. S. (2011). Pemberdayaan perempuan dari masa ke masa. Bogor: IPB Press.

Ibrahim, L. F., Seran, G. G., \& Pratidina, G. G. (2019). Implementasi Program Pemberdayaan Perempuan Korban Kekerasan dalam Rumah Tangga di Kota Bogor. Jurnal Governansi, 5(1), 89-97.

Imaniar, D. (2017). Pemberdayaan masyarakat pesisir (Perempuan nelayan) melalui pemanfaatan pengolahan limbah laut dan cangkang kerang. Jurnal Humaniora, 14(2), 62-66.

Indarwati, R. (2017). Strategi Pelaksanaan Tim Pemberdayaan Kesejahteraan Keluarga (PKK) dalam Meningkatkan Pemberdayaan Perempuan di Kecamatan Samarinda Utara. Jurnal Ilmu Pemerintahan, 5(2), 861-872.

Indriani, M. N. (2019). Pemberdayaan perempuan Bali dalam membuat upakara di Banjar Gemeh. Jurnal Sewaka Bhakti, 3(2), 10-24.

Kurniawanto, H., \& Anggraini, Y. (2019). Pemberdayaan perempuan dalam pengembangan badan usaha milik desa (Bumdes) melalui pemanfaatan potensi sektor pertanian (Studi kasus di Desa Kadu Ela Kecamatan Cadasari Kabupaten Pandeglang). Jurnal Kebijakan Pembangunan Daerah, 3(2), 127-137.

Marwanti, S., \& Astuti, I. D. (2012). Model pemberdayaan perempuan miskin melalui pengembangan kewirausahaan keluarga menuju ekonomi kreatif di Kabupaten Karanganyar. Sepa, 9(1), 134-144.

Mulyana, N., \& Asiah, D. H. S. (2017). Pemberdayaan perempuan melalui program Keluarga Berencana. Prosiding Penelitian dan Pengabdian kepada Masyarakat, 4(1), 93-103.

Rachmawati, E., Mujanah, S., \& Retnaningsih, W. (2018). Pengaruh Self Leadership, Kecerdasan Sosial, Employee Ability Terhadap Komitmen Organisasional dan Kinerja Karyawan Dinas Pengendalian Penduduk, Pemberdayaan Perempuan dan 
Perlindungan Anak Kota Surabaya.JMM17: Jurnal Ilmu Ekonomi dan Manajemen, 5(2), 113-135.

Saugi, W., \& Sumarno, S. (2015). Pemberdayaan perempuan melalui pelatihan pengolahan bahan pangan lokal. JPPM (Jurnal Pendidikan dan Pemberdayaan Masyarakat), 2(2), 226-238.

Sugiarti, Y., \& Sutrisni, S. (2020). Pemberdayaan Perempuan Melalui Wirausaha Pengolahan Buah Siwalan Di Desa Banuaju Timur Kecamatan Batang-Batang. Jurnal ABDIRAJA, 3(2), 15-17.

Sugiarti, Y., \& Sutrisni, S. (2020). Pemberdayaan Perempuan Melalui Wirausaha Pengolahan Buah Siwalan Di Desa Banuaju Timur Kecamatan Batang-Batang. Jurnal ABDIRAJA, 3(2), 15-17.

Sujarwo, S., Tristanti, T., \& Santi, F. U. (2017). Pengembangan model pemberdayaan perempuan desa wisata melalui pendidikan berbasis komunitas. Jurnal Penelitian Ilmu Pendidikan, 10(1), 75-85.

Supriyanti, M. (2017). Pemberdayaan Perempuan Pedesaan dalam Meningkatkan Pendapatan Keluarga Perspektif Ekonomi Islam (Doctoral dissertation, IAIN Purwokerto).

Syarif, A. (2018). Pemberdayaan perempuan menghadapi modernisasi pertanian melalui kelompok wanita tani (KWT) pada usahatani sayuran di Kecamatan Bissapu Kabupaten Bantaeng. Ziraa'ah Majalah Ilmiah Pertanian, 43(1), 77-84.

Tamba, W., Rizka, M. A., \& Andriani, I. (2020). Implementasi Pendidikan Masyarakat Melalui Pemberdayaan Perempuan Berbasis Life Skill Education. Jurnal Paedagogy, 7(3), 237-243.

Tini, D. L. R. (2019). Pengembangan Program Usaha Ekonomis Produktif dalam Pemberdayaan Perempuan di Kabupaten Sumenep. Jurnal Inovasi Ilmu Sosial Dan Politik (JISoP), 1(2), 148-156.

Tjiptaningsih, W. (2018). Pemberdayaan Perempuan Dalam Upaya Peningkatan Ekonomi Keluarga (Studi Kasus Pada Kelompok Usaha Perempuan di Desa Sindangkempeng Kecamatan Greged Kabupaten Cirebon). REFORMASI: Jurnal Ilmiah Administrasi, 2(1), 45-67.

Wardany, K., Sari, R. P., \& Mariana, E. (2020). Sosialisasi Pendirian "Bank Sampah" Bagi Peningkatan Pendapatan Dan Pemberdayaan Perempuan Di Margasari. Dinamisia: Jurnal Pengabdian Kepada Masyarakat, 4(2), 364-372.

Widianto, A. A. (2018). Aktivisme, Filantropi Sosial Dan Pemberdayaan Perempuan Di Yogyakarta: Studi terhadap Dinamika Aktivisme Yayasan Sahabat Ibu dalam Pemberdayaan Perempuan di Yogyakarta. Jurnal Sosiologi Reflektif, 12(2), 193-212.

Widiastuti, N., \& Kartika, P. (2017). Penerapan Model Kelompok Usaha Kreatif Islami (Kukis) Dalam Pemberdayaan Perempuan Berbasis Pondok Pesantren. Empowerment: Jurnal Ilmiah Program Studi Pendidikan Luar Sekolah, 6(2), 20-29. 